\title{
SIZE DEPENDENT APPLICATION OF BIOLOGICALLY SYNTHESIZED SILVER NANOPARTICLES AGAINST BACTERIAL SKIN PATHOGENS
}

\author{
PATIL SUNITA, MUTHUSAMY PALANISWAMY* \\ Department of Microbiology, School of Life Sciences, Karpagam University, Coimbatore - 641 021, Tamil Nadu, India. \\ Email: m.palamiswamy@gmail.com
}

Received: 08 May 2017, Received and Accepted: 23 June 2017

\section{ABSTRACT}

Objective: Bacterial skin infection is one of the most common causes of childhood morbidity in India. Mostly, it is caused by Streptococcus and Staphylococcus infections. However, because of antibiotic resistance in bacterial strains, treatment of skin infections is becoming increasingly difficult. The objective of this research is to study the effect of plant extract concentration on synthesis and morphology of biological silver nanoparticles and investigation of their activity against bacterial skin pathogens

Methods: Biological silver nanoparticles were synthesized using two concentrations (5 and 10 ml) of Aegle marmelos fruit pulp extract. Ultraviolet (UV)-visible spectroscopy, field emission scanning microscopy (FESEM), and high resolution transmission electron microscopy (HRTEM) were used to analyze morphological features of nanoparticles. Antibacterial activity of synthesized silver nanoparticles was studied against the most common skin pathogens Staphylococcus aureus and Streptococcus pyogen, using a well diffusion method.

Results: The silver nanoparticles synthesized from $5 \mathrm{ml}$ extract showed UV-absorbance peak at $430 \mathrm{~nm}$ with 14 -18 $\mathrm{nm}$ size, while silver nanoparticles synthesized from $10 \mathrm{ml}$ extract was showed the absorbance at $427 \mathrm{~nm}$ with 4-8 $\mathrm{nm}$ size. FESEM and HRTEM analysis revealed that both the silver nanoparticles were spherical in shape. Both nanoparticles have shown antibacterial activity among them silver nanoparticles synthesized from $10 \mathrm{ml}$ extract showed better antibacterial activity.

Conclusion: This research confirms that plant extract concentration modulate the rate of synthesis, morphology, surface plasmon resonance, and activity of biological silver nanoparticles. Silver nanoparticles synthesized from $10 \mathrm{ml}$ extract can be used efficiently in the treatment of bacterial skin infections.

Keywords: Silver nanoparticles, Aegle marmelos, Size, Bacterial skin pathogens, Antibacterial activity.

(C) 2017 The Authors. Published by Innovare Academic Sciences Pvt Ltd. This is an open access article under the CC BY license (http://creativecommons. org/licenses/by/4. 0/) DOI: http://dx.doi.org/10.22159/ajpcr.2017.v10i10.19718

\section{INTRODUCTION}

Human skin is host for many bacterial species that colonize as normal flora, but some bacteria have a potential to cause skin diseases. The most common skin diseases are infections and infestations (47.15\%) consisting of $58.09 \%$ bacterial infections [1]. The majority of bacterial skin infections are caused by the Gram-positive Staphylococcus and Streptococcus species, with occasional involvement of Gram-negative organisms [2]. Some common skin infections are impetigo, ecthyma, pyoderma, folliculitis, etc. [3]. Its treatment involves systematic antibiotics and local adjuvants. However, the prevalence of antibiotic resistance in bacteria with penicillin, erythromycin, tetracycline, fusidic acid, methicillin, vancomycin, and glycopeptides are more common [4]. Thus, there is a need of an effective and safe alternative treatment for treating skin infections caused by Streptococci and Staphylococci.

Green chemistry approach is an economic, environmental friendly and nontoxic way of nanoparticle synthesis. While chemical and physical methods of nanoparticle synthesis often use toxic chemicals and leave harmful environmental impact. Biological nanoparticle syntheses have been done using plants, bacteria, and fungi without nontoxic chemicals. Among them, plant extracts are extensively studied for nanoparticles synthesis as they have potential to produce nanoparticles with specific size, shape, and composition [5].

Aegle marmelos Corr. Family Rutaceae (Bael) is one of the most important medicinal plants available throughout the tropical countries [6]. Phytochemical screening of fruit extract showed the presence of alkaloids, flavonoids, steroids, terpenoids, phenols, tannin, carbohydrates, oil, and resins [7]. Its nutritional and medicinal properties are useful in diabetes, cancer osteoporosis, liver disorders, and as antioxidant, and anti-inflammatory [8].

Silver nanoparticles have been found to possess both antibacterial and anti-inflammatory properties [9-13]. Because of these properties, silver nanoparticles have been integrated into commercially available wound dressings, pharmaceutical preparations, and medical implant coatings [5]. The biological activities of silver nanoparticles are get influenced by its size thus better control on nanoparticle size requires during the process of synthesis. Two main factors that are responsible for nanoparticle size growth are metal salt and a reducing agent. Biological nanoparticle synthesis is bottom-up approach, in this technique plant extract reduces silver ions to atoms that get nucleate in the small cluster and produce nanoparticles. The availability of atoms is depends on metal ion and reducing agent ratio [14] by altering this ratio silver nanoparticle size can be modulated.

This research work involves the biological synthesis of two different sizes of silver nanoparticles 14-18 nm (SN5) and 4-8 nm (SN10) using $5 \mathrm{ml}$ and $10 \mathrm{ml}$ of $A$. marmelos fruit pulp extract. These nanoparticles were studied against common skin infecting bacteria Staphylococcus aureus and Streptococcus pyogene which gives an effective alternative to present antibiotics. This is the first attempt of study the correlation between plant extract concentration, morphology, and activity of biological silver nanoparticle. 


\section{MATERIALS AND METHODS}

Materials

Silver nitrate was purchased from Merck, India, and media was purchased from Himedia, India. Deionized water was used for preparing all solutions, extract, and media. Bacterial strains $S$. aureus (ATCC 25923) and S. pyogene (ATCC 1924) were obtained from the Department of Microbiology, Karpagam University.

\section{Synthesis of silver nanoparticles}

The selected plant was authenticated by Botanical Survey of India, Coimbatore. A. marmelos fruits were collected from the area of Coimbatore. The collected fruits were thoroughly surface cleaned by repeated washing. The fruit pulp was removed seeds were separated and was dried at $60^{\circ} \mathrm{C}$ for $48 \mathrm{hrs}$. Then, dried pulp was ground to coarse powder and stored in airtight container for further use. 2 gm of pulp powder was added in $100 \mathrm{ml}$ of double distilled water and heated at $80^{\circ} \mathrm{C}$ for 15 minutes. This extract was filtered with Whatman No. 1 filter paper. Silver nitrate solution $(0.1 \mathrm{mM})$ was prepared so that it gives final concentration $0.1 \mathrm{mM}$ after mixing with $5 \mathrm{ml}$ and $10 \mathrm{ml}$ of plant extract. The color of reaction solution was changed from light yellow to dark reddish brown that indicates the reduction of silver nitrate to $\mathrm{Ag}^{\circ}$. Complete bioreduction and presence of silver nanoparticles were confirmed by ultraviolet (UV)-visible spectrometry scanning. Synthesized silver nanoparticles were isolated and purified by centrifugation using $15000 \mathrm{rpm}$ speed for 10 minutes and washing repeatedly by dispersing in distilled water. Then, it was dried at room temperature and used further for antibacterial activity study. The silver nanoparticle synthesized from $5 \mathrm{ml}$ extract was named as SN5 and silver nanoparticle synthesized from $10 \mathrm{ml}$ extract was named as SN10.

\section{Characterization}

UV-Vis spectral analysis of colloidal solutions was performed in 800-200 nm spectral range using Shimadzu UV-2450 UV-Vis spectrophotometer. Field emission scanning microscopy (FESEM) of dried silver nanoparticles was observed under FEI - QUANTA-FEG 250 SEM microscope. High resolution transmission electron microscopy (HRTEM) of the silver nanoparticles was observed by placing $5 \mu \mathrm{L}$ of ethanolic suspension of silver nanoparticles on carbon coated copper grid followed by drying and observation under JEOL JEM 2100 HRTEM. The particle size of silver nanoparticle was calculated from HRTEM image using ImageJ software.

\section{Antibacterial activity}

Antibacterial activity of silver nanoparticles was analyzed against most common bacterial skin pathogens $S$. pyogene and $S$. aureus using $10^{5} \mathrm{CFU} / \mathrm{ml}$ by agar well diffusion method [15]. Three concentrations of colloidal silver nanoparticles in distilled water $50 \mu \mathrm{l} / \mathrm{ml}, 100 \mu \mathrm{g} / \mathrm{ml}$, and $150 \mu \mathrm{l} / \mathrm{ml}$ were used for antibacterial study with tetracycline $(50 \mu \mathrm{l} / \mathrm{ml})$ as a positive control and normal saline as a negative control. The zones of inhibition were observed after $24 \mathrm{hrs}$ of incubation period. Antibacterial activity analysis was performed 3 times and results were mentioned as a \pm standard deviation.

\section{RESULTS AND DISCUSSION}

\section{Synthesis of silver nanoparticles}

Reduction of silver nitrate was observed with time, the color of reaction mixture changed from light yellow to dark reddish brown as shown in Fig. 1. The reaction solution of $5 \mathrm{ml}$ extract showed slow color change in $8 \mathrm{hrs}$ while $10 \mathrm{ml}$ extract reaction solution showed color change within $3 \mathrm{hrs}$. These observations indicate higher the extract concentration faster the rate of silver nanoparticle synthesis. The rate biological silver nanoparticle synthesis also gets changed by plant extract constituents more the reducing components in extract faster the reaction. The leaf extract of Cymbopogon citratus showed silver nanoparticle synthesis within 24 hrs [16], while Terminalia Arjuna leaf extract showed it in just 15 minutes [17].

\section{UV-Vis analysis}

Complete reduction of silver nitrate and presence of silver nanoparticles were confirmed by UV-Vis spectrum of reaction solutions. The SN5and SN10 have shown the spectral peaks at $430 \mathrm{~nm}$ and $427 \mathrm{~nm}$, respectively. The difference in peak positions of SN5 and SN10 is due to the difference in their surface plasmonic properties. The collective oscillations of conduction electrons, which excited by electromagnetic radiation, are called surface plasmon resonances is a unique property of nanoparticles [18]. The larger particles give the absorbance band at the higher wavelength, so the SN5 are larger than SN10. The $5 \mathrm{ml}$ reaction solution shows smaller absorbance peak as compared to $10 \mathrm{ml}$ reaction solution (Fig. 2). There is slow growth in absorption peak of SN5 indicates slow maturation of particle during synthesis. This difference in peak size and position is because of change in optical properties of silver nanoparticles. The optical properties of nanoparticles are sensitive to size, shape, agglomeration, and concentration changes [19]. The previous reports of spherical silver nanoparticles showed the UVVis spectral absorption bands at around $400 \mathrm{~nm}$ [20]. In contrast, silver nanoparticles synthesized from Rhynchotechum ellipticum leaf extract showed broad spectrum band at the higher wavelength $459 \mathrm{~nm}$ with 51-73 $\mathrm{nm}$ particle size [21].

\section{FESEM analysis}

For observing the effect of plant extract concentration on the morphology of silver nanoparticles FESEM analysis was carried out in $3 \mu \mathrm{m}^{2}$ area using $\times 15000$ magnifications. Both SN5 and SN10 were spherical in shape. The FESEM micrograph (Fig. 3) shows that smaller spherical shaped particles aggregate into larger conglomerates this may be due to the stabilizer acquired from plant extract which was responsible for sample loading effect during attempts of receiving higher magnification [22]. Most of the biologically synthesized silver nanoparticles are spherical in shape, but exceptionally cubic silver nanoparticle also synthesized from Peltophorum pterocarpum plant extract [23]. For observing further details of morphology HRTEM analysis was performed.

\section{HRTEM analysis}

HRTEM images of SNPs are given in Fig 4 which confirms the spherical shape of silver nanoparticles. The biologically synthesized silver nanoparticles appear almost spherical in shape, and their intrinsic structure is dominantly a face-centered cubic lattice $[12,13]$. According to HRTEM image particle size of SN5 was $14-18 \mathrm{~nm}$ and SN10 was 4-8 $\mathrm{nm}$ (calculated using Image software). Histogram of particle size is shown in Fig. 5 which shows SN10 are smaller than SN5. From this observation, it is clear that plant extract concentration affects the particle size; use of higher plant extract concentration reduces the nanoparticle size.

\section{Antimicrobial activity against skin pathogens}

Both SN5 and SN10 silver nanoparticles showed antibacterial efficacy against selected microbial strains $S$. aureus and $S$. pyogene using $10^{5} \mathrm{CFU} / \mathrm{ml}$. SN10 showed higher antibacterial activity than SN5. In this study, tetracycline $(50 \mu \mathrm{L} / \mathrm{ml})$ was used as a positive control, and normal saline was used as a negative control. The obtained results are comparable with standard antibiotics. The zone of inhibition for three different concentrations of silver nanoparticles is given in Table 1 . The diameter of inhibition zone was increased with increasing concentration of silver nanoparticles. The SN10 had shown the larger zone of inhibition as compared to SN5, from which it is concluded that smaller particle size gives better penetration and good antimicrobial activity.

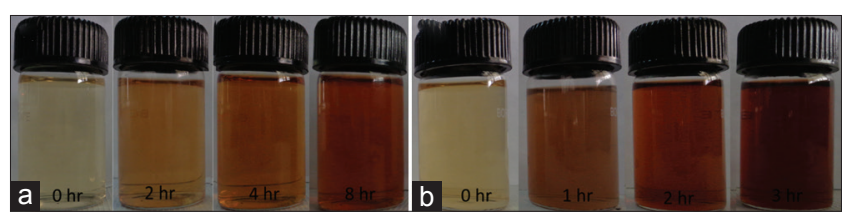

Fig. 1: Color change during silver nanoparticle synthesis (a) SN5 (b) SN10 


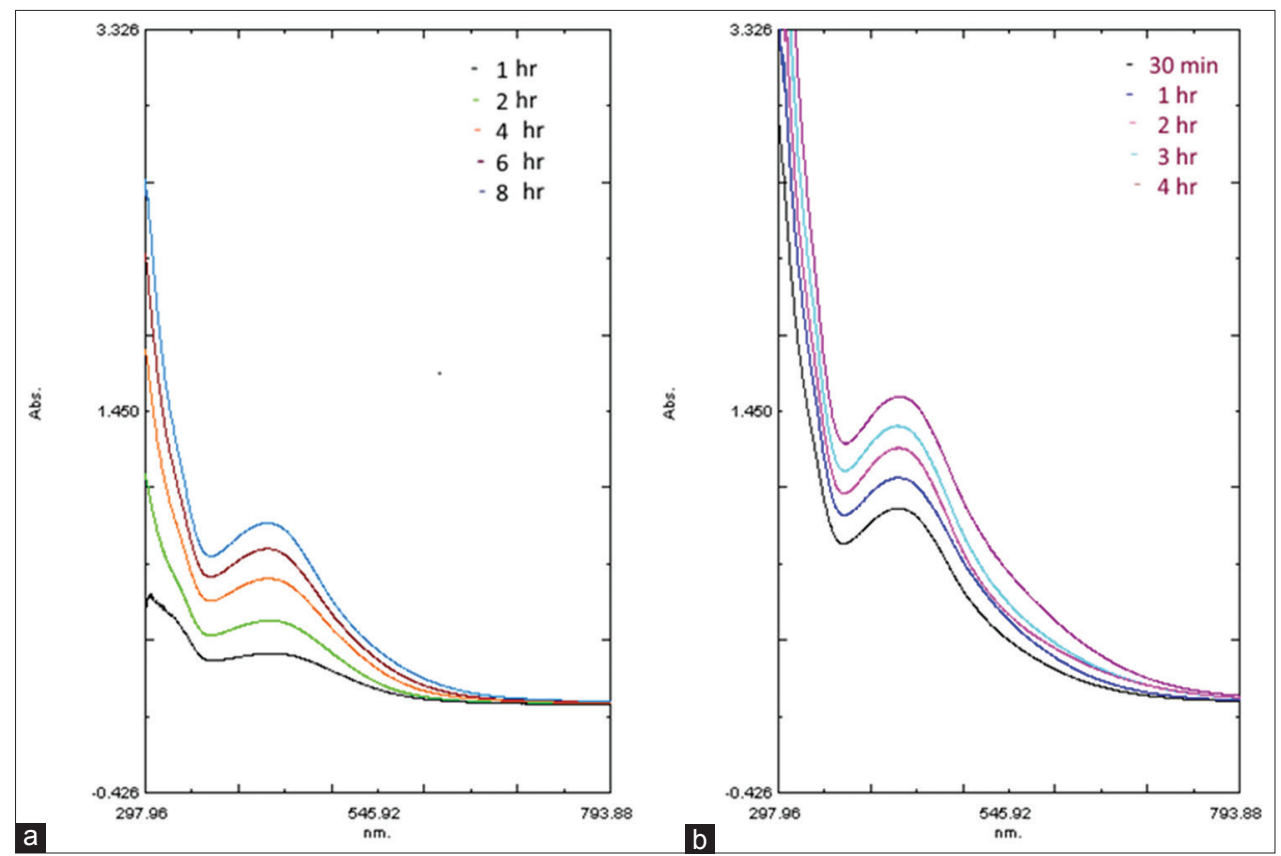

Fig. 2: Ultraviolet-visible spectrum of (a) SN5 and (b) SN10

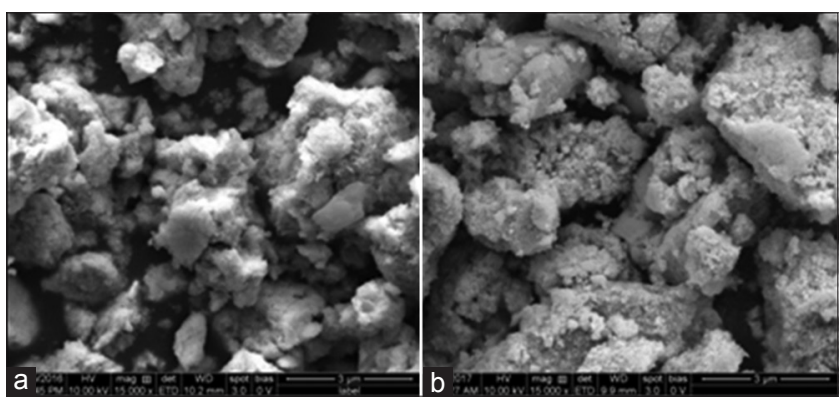

Fig. 3: Scanning electron micrograph of (a) SN5 (b) SN10

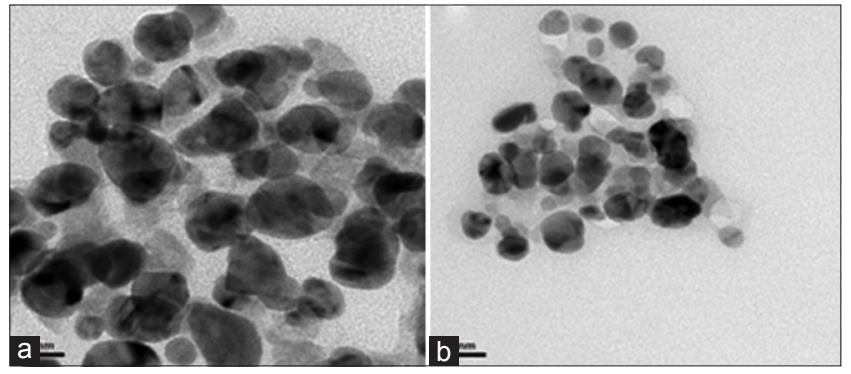

Fig. 4: High resolution transmission electron microscopy image of (a) SN5 and (b) SN10

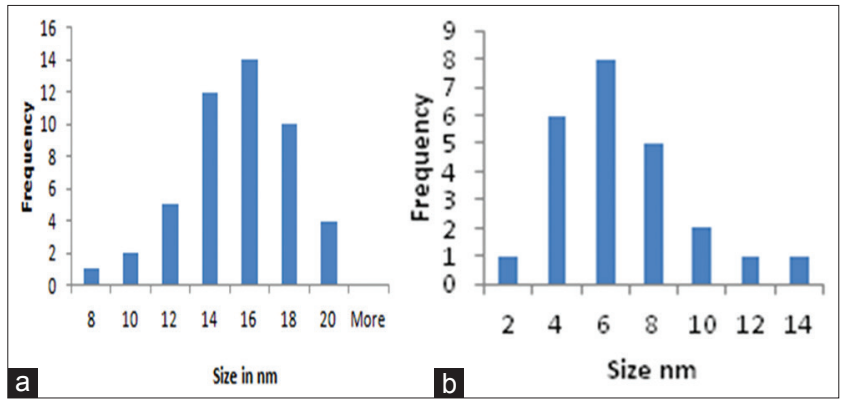

Fig. 5: Histogram of particle size (a) SN5 (b) SN10
Table 1: Antibacterial activity of SN5 and SN10 with control tetracycline

\begin{tabular}{lll}
\hline $\begin{array}{l}\text { Antibacterial } \\
\text { agent }(\mu \mathrm{g} / \mathrm{ml})\end{array}$ & $\begin{array}{l}\text { Zone of inhibition }(\mathbf{m m}) \text { with } \\
\text { mean } \pm \text { SD }\end{array}$ & S. pyogene \\
\cline { 2 - 3 } & S. aureus & \\
\hline SN5 & & $11 \pm 1$ \\
50 & $09 \pm 2$ & $12 \pm 2$ \\
100 & $11 \pm 3$ & $14 \pm 4$ \\
150 & $13 \pm 3$ & $14 \pm 2$ \\
SN10 & & $17 \pm 3$ \\
50 & $15 \pm 1$ & $19 \pm 3$ \\
100 & $17 \pm 2$ & $23 \pm 2$ \\
150 & $20 \pm 3$ & - \\
Tetracycline & & \\
50 & $21 \pm 2$ & \\
Normal saline & & \\
- & - & \\
\hline SD: Standard deviation, S. aureus: Staphylococcus aureus,
\end{tabular}

S. pyogene: Streptococcus pyogen

The strain of $S$. aureus was more susceptible than $S$. pyogene. These observations support the use of silver nanoparticles in the treatment of the bacterial skin infections. Result obtained from earlier studies supports the antibacterial activity of silver nanoparticles [24-26].

\section{CONCLUSION}

A. marmelos fruit pulp extract efficiently used as a reducing agent for synthesis of silver nanoparticles. The fruit pulp extract concentration modulates the rate of synthesis, size, optical properties, and activity of silver nanoparticles. The size of silver nanoparticle reduces with the higher concentration of fruit pulp extract. The objective of antibacterial activity against skin pathogens was fulfilled, as-synthesized silver nanoparticles showed effective antibacterial activity against common skin pathogens $S$. aureus and S. pyogene. The NP10 is more efficient antibacterial activity than NP5. This finding suggests the use of biological silver nanoparticles in adjuvant therapy of bacterial skin infection in the form of topical preparation. For fulfilling this objective further in vivo study and preparation of effective formulation needed to be done. 


\section{ACKNOWLEDGMENT}

We greatly acknowledge the Department of Science and Technology, India, for their financial support vide reference no SR/WOS-A/LS$1196 / 2015$ under Woman Scientist Scheme A to carry out this work. We acknowledge Karpagam University, Bharathiar University, and PSG Institute of Advanced Studies for instrumentation facilities provided throughout this research.

\section{REFERENCES}

1. Sardana K, Mahajan S, Sarkar R, Mendiratta V, Bhushan P, KoranneRV, et al. The spectrum of skin disease among Indian children. Pediatr Dermatol 2009;26(1):6-13.

2. Palit A, Inamadar AC. Current concepts in the management of bacterial skin infections in children. Indian J Dermatol Venereol Leprol 2010;76(5):476-88.

3. Tomecki KJ. Common skin infections. Dis Manage 2010;2:1-6.

4. Perera G, Hay R. A guide to antibiotic resistance in bacterial skin infections. J Eur Acad Dermatol Venereol 2005;19(5):531-45.

5. Shah M, Fawcett D, Sharma S, Tripathy SK. Green synthesis of metallic nanoparticles via biological entities. Materials 2015;8(11):7278-308.

6. Anurag S, Sing HK, Pragati K, Ashutosh U. Bael (Aegle marmelos Correa) products processing: A review. Afr J Food Sci 2014;8(5):204-15.

7. Nirmala A, Manimekalai G, Vasanthi P, Jagajothi A, Evanjelene VK, $\mathrm{Nadu} \mathrm{T}$, et al. In vitro antimicrobial, phytochemical analysis of Marmelos fruit extracts. World J Pharm Pharm Sci 2016;5(7):803-11.

8. Gautam MK, Ghatule RR, Singh A, Purohit V, Gangwar M, Kumar M, et al. Healing effects of Aegle marmelos (L.) Correa fruit extract on experimental colitis. Indian J Exp Biol 2013;51(2):157-64.

9. Gnanajobitha G, Paulkumar K, Vanaja M, Rajeshkumar S, Malarkodi C, Annadurai G, et al. Fruit-mediated synthesis of silver nanoparticles using Vitis vinifera and evaluation of their antimicrobial efficacy. J Nano Chem 2013;3:67.

10. Priyaragini S, Sathishkumar SR, Bhaskararao KV. Biosynthesis of silver nanoparticles using actinobacteria and evaluating its antimicrobial and cytotoxicity activity. Int J Pharm Pharm Sci 2013;5 Suppl 2:709-12.

11. Parimala KS, Balaji S, Nithiyasoundari M. Synthesis of silver nanoparticles using different types of ornamental flower extracts and its antibacterial activity. Int J Curr Res 2015;7(8):18876-80.

12. Patil S, Sivaraj R, Rajiv P, Venckatesh R, Seenivasan R. Green synthesis of silver nanoparticle from leaf extract of Aegle marmelos and evaluation of its antibacterial activity. Int $\mathrm{J}$ Pharm Pharm Sci 2015;7(6):169-73.

13. Mani KM, Seethalakshmi S, Gopal V. Evaluation of in-vitro antiinflammatory activity of silver nanoparticles synthesized using Piper nigrum extract. J Nanomed Nanotechnol 2015;6(2):1-5.

14. Rodríguez-León E, Iñiguez-Palomares R, Navarro RE, Herrera-Urbina R, Tánori J, Iñiguez-Palomares C, et al. Synthesis of silver nanoparticles using reducing agents obtained from natural sources (Rumex hymenosepalus extracts). Nanoscale Res Lett 2013;8(1):318.

15. Lino A, Deogracious O. The in-vitro antibacterial activity of Annona senegalensis, Securidacca longipendiculata and Steganotaenia araliacea - Ugandan medicinal plants. Afr Health Sci 2006;6(1):31-5.

16. Ndikau M, Noah NM, Andala DM, Masika E. Green Synthesis and Characterization of Silver Nanoparticles Using Citrullus lanatus Fruit Rind Extract. Int J Anal Chem 2017;2017:8108504.

17. Ahmed S, Ikram S. Silver nanoparticles: One pot green synthesis using Terminalia arjuna extract for biological application. J Nanomed Nanotechnol 2015;6(4):1-6.

18. Evanoff DD Jr, Chumanov G. Synthesis and optical properties of silver nanoparticles and arrays. Chemphyschem 2005;6(7):1221-31.

19. Tomaszewska E, Soliwoda K, Kadziola K, Tkacz-Szczesna B, Celichowski G, Cichomski M, et al. Detection limits of DLS and UVVis spectroscopy in characterization of polydispersity nanoparticles colloids. J Nanomater 2013;2013:10.

20. Maiti S, Krishnan D, Barman G, Ghosh SK, Laha JK. Antimicrobial activities of silver nanoparticles synthesized from Lycopersicon esculentum extract. J Anal Sci Technol 2014;5(1):40.

21. Hazarika D, Phukan A, Saikia E, Chetia B. Phytochemical screening and synthesis of silver nanoparticles using leaf extract of Rhynchotechum ellipticum. Int J Pharm Pharm Sci 2014;6(1):672-4.

22. Puchalski M, Dąbrowski P, Olejniczak W, Krukowski P, Kowalczyk P, Polański K. The study of silver nanoparticles by scanning electron microscopy, energy dispersive X-ray analysis and scanning tunnelling microscopy. Mater Sci 2007;25(2):473-8.

23. Sivakumar P, Karthika P, Sivakumar P, Muralidharan NG, Devendran P, Renganathan S. Bio-synthesis of silver nano cubes from active compound quercetin-3-o- $\beta$-dgalactopyranoside containing plant extract and its antifungal application. Asian J Pharm Clin Res 2013;6 Suppl 4:76-9.

24. Bhakya S, Muthukrishnan S, Sukumaran M, Muthukumar M. Biogenic synthesis of silver nanoparticles and their antioxidant and antibacterial activity. Appl Nanosci 2015;6(5):1-12.

25. Sulaiman GM, Hussien HT, Saleem M. Biosynthesis of silver nanoparticles synthesized by Aspergillus flavus and their antioxidant, antimicrobial and cytotoxicity properties. Bull Mater Sci 2015;38(3):639-44.

26. Murugesan S, Bhuvaneswari S, Sivamurugan V. Green synthesis, characterization of silver nanoparticles of a marine red alga Spyridia fusiformis and their antibacterial activity. Int J Pharm Pharm Sci 2017;9(5):192-7. 